\title{
IDH2 Gene Mutation Negative
}

National Cancer Institute

\section{Source}

National Cancer Institute. IDH2 Gene Mutation Negative. NCI Thesaurus. Code C148087.

A genetic finding indicating that IDH2 gene mutations have not been detected in a sample. 